\title{
"Tax policy and housing prices: evidence from Vietnam using event study approach"
}

AUTHORS

ARTICLE INFO

RELEASED ON

RECEIVED ON

ACCEPTED ON

LICENSE

JOURNAL

ISSN PRINT

ISSN ONLINE

PUBLISHER

FOUNDER
Pham Huu Hong Thai (D https://orcid.org/0000-0003-1262-6492

Hao Manh Quach (D https://orcid.org/0000-0002-0456-2065

Pham Huu Hong Thai and Hao Manh Quach (2017). Tax policy and housing prices: evidence from Vietnam using event study approach. Investment Management and Financial Innovations, 14(4), 121-132.

doi:10.21511/imfi.14(4).2017.11

http://dx.doi.org/10.21511/imfi.14(4).2017.11

Thursday, 21 December 2017

Tuesday, 14 November 2017

Wednesday, 13 December 2017

\section{(oc) EY-NG}

This work is licensed under a Creative Commons Attribution-NonCommercial 4.0 International License

"Investment Management and Financial Innovations"

$1810-4967$

$1812-9358$

LLC "Consulting Publishing Company "Business Perspectives"

LLC "Consulting Publishing Company "Business Perspectives"
NUMBER OF REFERENCES

39
NUMBER OF FIGURES

2
NUMBER OF TABLES

5

(C) The author(s) 2022. This publication is an open access article. 


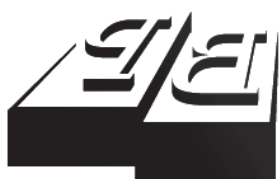

BUSINESS PERSPECTIVES

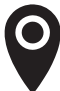

LLC "CPC "Business Perspectives" Hryhorii Skovoroda lane, 10, Sumy, 40022, Ukraine

www.businessperspectives.org

Received on: $14^{\text {th }}$ of November, 2017 Accepted on: $13^{\text {th }}$ of December, 2017

(c) Pham Huu Hong Thai, Hao Manh Quach, 2017

Pham Huu Hong Thai, Dr., Associate Professor, University of Finance Marketing, Vietnam.

Hao Manh Quach, Senior Lecturer in Finance, University of Lincoln United Kingdom.
Pham Huu Hong Thai (Vietnam), Hao Manh Quach (United Kingdom)

\section{TAX POLICY AND HOUSING PRICES: EVIDENCE FROM VIETNAM USING EVENT STUDY APPROACH}

\begin{abstract}
This paper examines the effect of tax policy on housing prices in Vietnam for the period from October 2004 to September 2016 using event study approach. The authors find that all five key changes made to the personal income tax, corporate income tax and non-farm land use tax have caused the housing prices to decline on average 6-11\% during the event window, but only the impact of the personal income tax changes is statistically significant. The fact that changes in housing prices are mostly seen prior to the effective date of the tax policy change implies that tax policy change indeed has influenced the housing prices in Vietnam. Although this research has not examined the mechanism through which tax policy has influenced the housing prices, the findings offer some implications for the government in terms of using tax policy for controlling housing prices in Vietnam. The research is also of very few papers in this literature that use the event study approach.
\end{abstract}

Keywords taxation, tax policy, housing prices, event study, Vietnam

JEL Classification $\quad \mathrm{C} 10, \mathrm{H} 73, \mathrm{H} 22$

\section{INTRODUCTION}

The relationship between taxation and housing prices has been documented in the literature with little evidence. Most research studies have sought for the connections between housing market, including level of investments and prices, and economic variables in general. Various factors have been identified as having influenced the housing market, such as the income level (Mikhed \& Zemcik, 2009; Goodhart \& Hofmann, 2008; Madsen, 2012), taxation (Turnovsky \& Okuyama, 1994), credit supply (Adams \& Füss, 2010; Leung, 2004; Goodhart \& Hofmann, 2008), interest rates (Apergis \& Rezitis, 2003; Igan et al., 2011; Goodhart \& Hofmann, 2008; Zan \& Wang, 2012), inflation rates (Kearl, 1979; Follain, 1982; Madsen, 2012; Apergis \& Rezitis, 2003; Bork \& Muller, 2016), employment (Lerbs, 2011; Giussani et al., 1992; Baffoe-Bonnie, 1998), or the demographic characteristics (Mankiw \& Weil, 1989).

The direct effect of tax policy on housing prices, however, has been limitedly documented. The indirect effect could be interpreted through the role of investments and demand in housing markets (see, for example, ECB, 2009; Andrews, 2010; Poterba, 1992; Skinner, 1996; Gervais, 2002; Feldstein, 1982; Berkovec \& Fullerton, 1992). Some very few papers have estimated the direct effect of tax policy on housing prices (see, for example, Goulder, 1989; Best \& Kleven, 2017; Bai et al., 2014; Du \& Zhang, 2015; Capozza et al., 1998; Rosenthal, 1999). This literature, although limited, has shown that tax policy is important to determining housing prices. 
In Vietnam, housing prices surged 2.6 times between October 2004 and September 2016. The housing prices rose rapidly between October 2004 and mid-2008, but have been increasing slowly since then (General Statistics Office, 2017). The main characteristic of the housing market in Vietnam is that it was dominated by speculative investments, in which many buyers were simply investors rather than end users. The major changes in terms of tax policies relating to the housing market have been introduced after the mid-2008 in an attempt to curb the housing prices and to stabilize the market. The government, therefore, wants to see if the tax policy, and which taxes, have indeed influenced the housing prices.

This paper examines the effect of tax policy on housing prices in Vietnam. The findings are expected to offer some policy recommendations for Vietnamese government to monitor the housing prices through their taxation. As far as the authors know, this paper is the first to gauge the role of tax policies on housing prices in Vietnam, and perhaps of very few papers in this literature that use event study approach. Five events representing five key tax policy changes relating to housing markets are examined. Among others, our findings suggest that all tax policy changes caused the housing prices to decline on average by $6-11 \%$ for the 13 month event window. However, in terms of statistical significance, the decline in housing prices is significantly related to the changes made to personal income tax.

The rest of our paper is structured as follows. The next section provides some brief literature on the effect of taxation on housing prices and the tax policy in Vietnam. Then, the methodology section presents details of our event study framework and discuss the data sample. Section 3 reports the test results and discussions. The last section offer some concluding remarks and recommendations to policy makers.

\section{LITERATURE REVIEW}

\subsection{The effect of tax policy on housing prices}

The relationship between tax policy and housing prices is mostly interpreted indirectly through mechanisms such as investments and demand in housing markets. For example, tax deductions are seen as one of the main drivers for higher investments in housing markets in European countries, which, in turn, potentially result in lower housing prices (ECB, 2009; Andrews, 2010). Another study by Poterba (1992) examines the effect of tax reforms on housing market in the United States in 1986 and finds that tax reforms reduce incentive for rental housing investment, contributing to the decline in multifamily housing starts and, in the long run, will lead to higher rents. Other studies (see, for example, Skinner, 1996; Gervais, 2002; Feldstein, 1982, 2009; Berkovec \& Fullerton, 1992; Turnovsky \& Okuyama, 1994) have shown different results for the effect of tax policies on level of investments in housing markets and implied that in the long term, these effects would influence housing prices.
Of very few papers that examine directly the effect of tax policy on housing prices, Goulder (1989) studies the 1986 Tax Reforms in the United States using a general equilibrium model and concludes that in the short term, the reductions in corporate tax rates and the elimination of investment tax credits have positive effects on housing investment, suggesting that a favorable corporate income tax policy would decrease the housing prices in the short run. Other researchers such as Best and Kleven (2017) on UK market look at the cost of housing transactions and find that transaction taxes play an important role in housing prices, and that housing prices respond very quickly to changes in transaction taxes. In another study, Capozza et al. (1998) assess the impact of income and property taxes on housing prices and find that the proposed tax changes result in substantial house price declines. They emphasize that if local governments raise property tax rates to offset the impact of the decline in housing prices on their tax revenues, prices fall further.

The literature, although limited, also sees interesting but contradicting findings even if the same tax policy and sample are considered. Bai et al. (2014) explore the influence of a trial property tax policy 
on housing prices in two provinces in China and find different effects: the tax policy helps lower housing prices in one province, but raises prices in other province. Examining the same property tax policy in the same two provinces, Du and Zhang (2015), however, find inverse conclusions: they find that the tax policy reduces the annual growth rate of housing prices in the province where Bai et al. (2014) had found an increase in housing prices; and they do not find significant effect of the tax policy on housing prices in the other province that have been found significantly lower in Bai et al. (2014).

The above literature suggests that although different types of taxes are examined and the findings suggest mixed conclusions, it is safe to conclude that tax policy changes are important to influence housing market and prices. In other words, the governments may utilize various tax policies if they want to influence and control housing market through its prices. As shown in the literature, the most common channels for this influence to happen are through the level of investment in housing market made by developers and the demand for houses from home buyers (Goulder, 1989; Andrews, 2010).

\subsection{Tax policy and housing prices in Vietnam}

Figure 1 depicts the housing prices in Vietnam from October 2004 until September 2016. Within the period, the house prices increased on average 2.6 times. There was a significant increase in the housing prices during the period until mid-year 2008. The housing prices since mid-year 2008 look to have been stable. This is also the period where the key changes in tax policies relating to housing market were introduced, inducing us to think about the role of tax policy changes on the prices.

The major changes in tax policies in Vietnam relating to housing markets have happened since the introduction of the new Laws on Personal Income Tax which was effective from January 2009. The key change as compared to the law that had been in effect from 1992 was the inclusion of a specific clause for incomes gained from real estate and house sales, which imposes tax charges based on market price basis, rather than on the framed price regulated by the government (National Assembly,
2007). This change eventually implies a higher tax charge than before for an identical transaction.

The law was later modified in July 2013 by specifying that the transfer of housing ownership in all forms must be subject to taxation (National Assembly, 2013a). This addition was important, because until that time, the sale contracts under the form of authorized contracts, which do not transfer the ownership, had been popular and sellers had avoided tax charges under the law introduced in 2009. Another modification was in January 2015, which required the application of one-for-all tax rate of $2 \%$ on the market price rather than the choice of $2 \%$ on market price or $25 \%$ on the capital gains (National Assembly, 2014). This modification made it easy to calculate the tax, but more importantly, it cleared off the possibility of tax avoidance resulting from the fact that sellers could easily manipulate to reduce the capital gains. In the end, the two modifications, to some extent, have tightened the income tax law on incomes from housing sales by making tax avoidance more difficult to achieve.

The other two policies include the modification to the corporate income tax in effect from January 1, 2014 (National Assembly, 2013b) and the law on non-farm land use tax effective from January 1 , 2012 (National Assembly, 2011). The modification to the corporate income tax considered the income from housing and real estate sales, which had been considered separately prior to that as a source of total corporate taxable income. This was a good news to companies, because if the housing market went down, they could benefit from tax reduction. The law on non-farm land use tax, however, is a negative factor to the housing market, as it implied higher tax charges and thus higher costs for houses which obviously are built on non-farm land.

The key tax policy changes above were all expected to stabilize and make the housing market more transparent. An assessment on the effectiveness of those policy changes may be important for policy makers. A research such as the impact of tax policy changes on housing prices in Vietnam, however, has not been available. One reason could be the lack of data. This research therefore is expected to be the first to contribute to this literature with Vietnamese context. 
Housing Price Index from October 2004 to September 2016

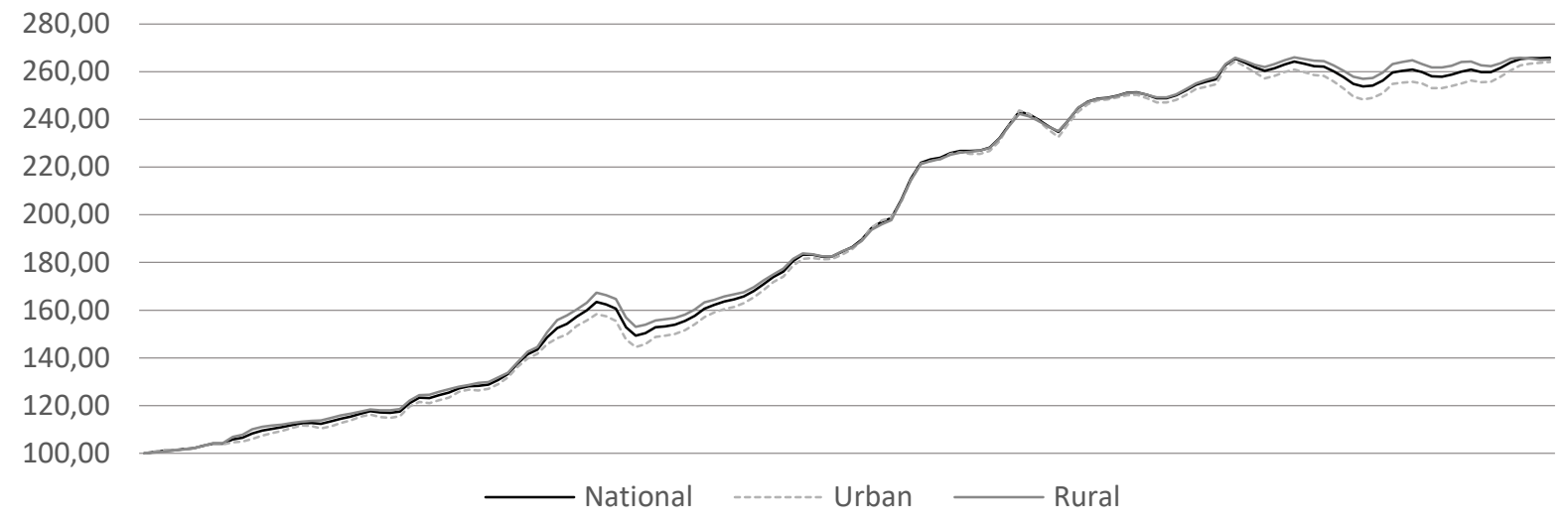

Figure 1. Housing prices in Vietnam

\section{METHODS}

\subsection{Event study method}

To estimate the relationship between the housing prices and tax policies, we employ the event study approach. Our approach is different from most of related literature on housing prices and tax policy, which normally uses regression models to gauge the relationship between housing prices and other macro variables, including tax policy related variables. Specifically, we employ the standard event study approach (see MacKinlay, 1997), in which the effective dates of tax policy changes passed through by the National Assembly are used as the event dates. By following this approach, we consider the changes in house prices just like changes in the price of a financial asset.

Following framework suggested by MacKinlay (1997), in our model, events are the policy changes and the house price changes, or returns, are indexed in event time $\tau$. We define the event date as $\tau=0$ and $\tau=T_{1}+1$ to $\tau=T_{2}$ represents the event window, while $\tau=T_{0}+1$ to $\tau=T_{1}$ is the estimation window. The length of estimation window is denoted as $L_{1}=T_{1}-T_{0}$ and $L_{2}=T_{2}-T_{1}$ to be the event window. The time frame is as follows:

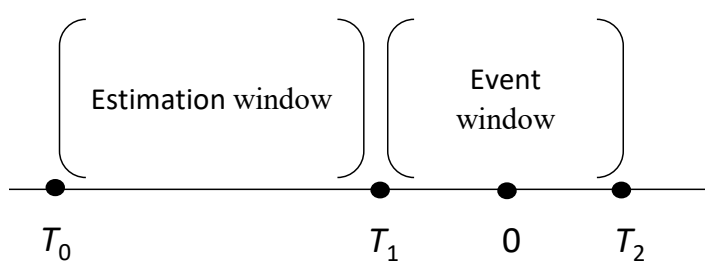

Figure 2. Event and estimation window
The estimation of abnormal return - the difference between the actual return and the normal return - is implemented using two popular methods, the constant mean return and the market model return. With constant mean return method, the normal return is estimated using the following equation:

$R_{h, t}=\mu_{h}+\varepsilon_{h, t}$; with $E\left(\varepsilon_{h, t}\right)=0$ and $\operatorname{var}\left(\varepsilon_{h, t}\right)=\sigma_{\varepsilon_{h}}^{2}$,

where $\mu_{h}$ is the mean return on asset $h, R_{h, t}$ is the period $t$ return on asset hand $\varepsilon_{h, t}$ is the time period $t$ disturbance term with an expectation of zero and variance $\sigma_{\varepsilon_{h}}^{2}$.

With market model return method, we use the following equation:

$R_{h, t}=\alpha_{h}+\beta_{h} \cdot R_{m, t}+\varepsilon_{h, t}$ with $E\left(\varepsilon_{h, t}\right)=0$ and $\operatorname{var}\left(\varepsilon_{h, t}\right)=\sigma_{\varepsilon_{h}}^{2}$,

where $R_{h, t}$ and $R_{m, t}$ are the period $t$ returns on asset $h$ and the market, $\alpha_{h}, \beta_{h}$ and $\sigma_{\varepsilon_{h}}^{2}$ are the parameters of the market model. Using the ordinary least squares (OLS) method, these parameters for the estimation window of observations are calculated as follows:

$$
\begin{gathered}
\widehat{\beta}_{h}=\frac{\sum_{\tau=T_{0}+1}^{T_{1}}\left(R_{h, \tau}-\widehat{\mu}_{h}\right) \cdot\left(R_{m, \tau}-\widehat{\mu}_{m}\right)}{\sum_{\tau=T_{0}+1}^{T_{1}}\left(R_{m, \tau}-\widehat{\mu}_{m}\right)^{2}} \\
\widehat{\alpha}_{h}=\widehat{\mu}_{h}-\widehat{\beta}_{h} \cdot \widehat{\mu}_{m}
\end{gathered}
$$




$$
\widehat{\sigma_{\varepsilon_{h}}^{2}}=\frac{1}{L_{1}-2} \sum_{\tau=T_{0}+1}^{T_{1}}\left(R_{h, \tau}-\widehat{\alpha}_{h}-\widehat{\beta}_{h} \cdot R_{m, \tau}\right)^{2}
$$

where

$$
\widehat{\mu}_{h}=\frac{1}{L_{1}} \sum_{\tau=T_{0}+1}^{T_{1}} R_{h, \tau}
$$

and

$$
\widehat{\mu_{m}}=\frac{1}{L_{1}} \sum_{\tau=T_{0}+1}^{T_{1}} R_{m, \tau}
$$

Let $\widehat{A R_{h, \tau}}, \tau=T_{1}+1, \ldots, T_{2}$ be the sample of $L_{2}$ abnormal returns in the event window, the sample abnormal returns are estimated. Under the constant mean return approach, the abnormal returns are:

$$
\widehat{A R_{h, \tau}}=R_{h, \tau}-\mu_{h}
$$

And under the market return model, the abnormal returns are:

$$
\widehat{A R_{h, \tau}}=R_{h, \tau}-\widehat{\alpha}_{h}-\widehat{\beta}_{h} \cdot R_{m, \tau}
$$

Statistically, under the null hypothesis, conditional on the event window market returns, the abnormal returns will be jointly normally distributed with a zero conditional mean and conditional variance $\sigma^{2}\left(\frac{A_{i, \tau}}{}\right)$ where

$$
\sigma^{2}\left(\widehat{A R_{h, \tau}}\right)=\sigma_{\varepsilon_{h}}^{2}+\frac{1}{L_{1}} \cdot\left[1+\frac{\left(R_{m, \tau}-\widehat{\mu_{m}}\right)^{2}}{\widehat{\sigma_{m}^{2}}}\right]
$$

As noted in Mac Kinlay (1997), in the above equation, the conditional variance has two components. One component is the disturbance variance $\sigma_{\varepsilon_{h}}^{2}$ and a second component is additional variance due to the sampling error in $\alpha_{h}$ and $\beta_{h}$. The sampling error leads to serial correlation of the abnormal returns despite the fact that the true disturbances are independent through time. As shown in equation (11), if the estimation window $L_{1}$ is large enough, we can assume that the variance of the abnormal return observations will be $\sigma_{\varepsilon_{h}}^{2}$ and the abnormal return observations will become independent through time.Under null hypothesis the distribution of the sample abnormal return of a given observation in the event window is:

$$
\widehat{A R_{h, \tau}} \sim N\left(0, \sigma^{2}\left(\widehat{A R_{h, \tau}}\right)\right)
$$

It is also common in event study to examine the Cumulative Abnormal Return (CAR) because individual abnormal returns do not say much about the overall role of the event. We define the $C_{A} A R_{h, \tau}\left(\tau_{1}, \tau_{2}\right)$ as the sample cumulative return from $\tau_{1}$ to $\tau_{2}$, where $T_{1}<\tau_{1} \leq \tau_{2} \leq T_{2}$ :

$$
\operatorname{CAR}_{h, \tau}\left(\tau_{1}, \tau_{2}\right)=\sum_{\tau=\tau_{1}}^{\tau_{2}} A R_{h, \tau}
$$

As $L_{1}$ increases the variance of $C A R_{h, \tau}\left(\tau_{1}, \tau_{2}\right)$ is

$$
\sigma_{h}^{2}\left(\operatorname{CAR}\left(\tau_{1}, \tau_{2}\right)\right)=\left(\tau_{2}-\tau_{1}+1\right) \cdot \sigma_{\varepsilon_{h}}^{2}
$$

The distribution of the CAR under null hypothesis is

$$
\operatorname{CAR}_{h, \tau}\left(\tau_{1}, \tau_{2}\right) \sim N\left(0, \sigma_{h}^{2}\left(\operatorname{CAR}\left(\tau_{1}, \tau_{2}\right)\right)\right)
$$

\section{DATA}

The data used for this research are collected and compiled from various sources, including the General Statistic Office of Vietnam, the Government of Vietnam Data Portal, the Ministry of Finance Data Portal, and the State Bank of Vietnam. Data is collected for a period from October 2004 until September 2016. The data include monthly housing price index for the whole country, the urban and rural areas, which are used to calculate returns on a housing portfolio, and monthly stock market index return, which is used as proxy for general market return.

We also collect the data on dates of key policy changes, including the change in personal income tax, change in corporate income tax and change in tax of non-farm land use. We select only changes that are applicable to real estate and housing markets. There are 5 event dates in which three are attributed to changes in personal income tax and one to corporate income tax and one to nonfarm land use tax. All policy changes are expected to make the housing markets more regulated by reducing the possibility for tax avoidance from house sales and transfers. 


\section{RESULTS AND DISCUSSIONS}

Five tax policy changes are selected for the event study tests. The personal income tax law, in which for the first time incomes from real estate and housing sales were distinguished from other incomes and legalized, was introduced to be in affect from January 1, 2009. Further modifications with respect to the income from housing sales and transfer were made to be effective on July 1 , 2013 and January 1, 2015. These modifications both specified conditions that eventually ensure the income tax avoidance relating to housing sales and ownership transfers is less possible. All of the three major personal income tax changes are considered to be negative to the real estate and housing markets. The other two policies include the modification to the corporate income tax in effect from January 1, 2014 and the law on nonfarm land use tax effective from January 1, 2012. The modification to the corporate income tax considered the income from real estate sales as a source of total corporate taxable income that had been considered separately before. This is considered to be good news to companies, but it basically encourages companies to report losses from sales of real estates. The law on non-farm land use tax is another negative factor to the housing market, as it tightened further the room for potential tax avoidance resulting from the confusion of types of sales and ownership contracts.

Table 1. Effect of the introduction of personal income tax law on housing price

\begin{tabular}{|c|c|c|c|c|c|c|c|c|c|c|c|c|}
\hline \multicolumn{13}{|c|}{ Constant Mean Return } \\
\hline \multicolumn{5}{|c|}{ National } & \multicolumn{4}{|c|}{ Urban } & \multicolumn{4}{|c|}{ Rural } \\
\hline$\tau$ & $A R, \%$ & t-stat & CAR, \% & t-stat & $A R, \%$ & t-stat & CAR, \% & t-stat & $\mathrm{AR}, \%$ & t-stat & CAR, \% & t-stat \\
\hline-6 & 0.60 & 0.62 & 0.60 & 0.62 & 0.47 & 0.46 & 0.47 & 0.46 & 0.73 & 0.70 & 0.73 & 0.70 \\
\hline-5 & 1.11 & 1.15 & 1.72 & 1.25 & 0.79 & 0.78 & 1.27 & 0.88 & 1.43 & 1.37 & 2.17 & 1.47 \\
\hline-4 & -1.70 & -1.75 & 0.02 & 0.01 & -1.65 & -1.61 & -0.38 & -0.21 & -1.74 & -1.66 & 0.43 & 0.24 \\
\hline-3 & -2.15 & -2.21 & -2.12 & -1.09 & -2.22 & -2.17 & -2.60 & -1.27 & -2.06 & -1.97 & -1.63 & -0.78 \\
\hline-2 & -5.93 & -6.11 & -8.05 & -3.71 & -6.03 & -5.90 & -8.62 & -3.77 & -5.83 & -5.58 & -7.45 & -3.19 \\
\hline-1 & -3.43 & -3.53 & -11.47 & -4.83 & -3.12 & -3.05 & -11.74 & -4.69 & -3.68 & -3.52 & -11.13 & -4.35 \\
\hline 0 & -0.30 & -0.30 & -11.77 & -4.59 & -0.08 & -0.07 & -11.82 & -4.37 & -0.49 & -0.47 & -11.62 & -4.20 \\
\hline 1 & 0.52 & 0.54 & -11.24 & -4.10 & 1.04 & 1.02 & -10.77 & -3.73 & 0.07 & 0.07 & -11.55 & -3.91 \\
\hline 2 & -0.77 & -0.79 & -12.01 & -4.13 & -0.64 & -0.62 & -11.41 & -3.72 & -0.88 & -0.84 & -12.42 & -3.96 \\
\hline 3 & -0.62 & -0.63 & -12.62 & -4.12 & -0.50 & -0.49 & -11.91 & -3.68 & -0.70 & -0.67 & -13.12 & -3.97 \\
\hline 4 & -0.10 & -0.10 & -12.72 & -3.96 & 0.02 & 0.02 & -11.88 & -3.51 & -0.21 & -0.20 & -13.33 & -3.85 \\
\hline 5 & 0.38 & 0.40 & -12.33 & -3.67 & 0.63 & 0.62 & -11.25 & -3.18 & 0.18 & 0.18 & -13.14 & -3.63 \\
\hline 6 & 0.82 & 0.85 & -11.51 & -3.29 & 0.92 & 0.90 & -10.32 & -2.80 & 0.73 & 0.70 & -12.41 & -3.30 \\
\hline \multicolumn{13}{|c|}{ Market Model Return } \\
\hline \multicolumn{5}{|c|}{ National } & \multicolumn{4}{|c|}{ Urban } & \multicolumn{4}{|c|}{ Rural } \\
\hline$\tau$ & $A R, \%$ & t-stat & CAR, \% & t-stat & $A R, \%$ & t-stat & CAR, \% & t-stat & $\mathrm{AR}, \%$ & t-stat & CAR, \% & t-stat \\
\hline-6 & 0.75 & 0.79 & 0.75 & 0.79 & 0.55 & 0.54 & 0.55 & 0.542 & 0.93 & 0.90 & $0.93 \%$ & 0.90 \\
\hline-5 & 1.34 & 1.41 & 2.09 & 1.55 & 0.95 & 0.94 & 1.50 & 1.049 & 1.71 & 1.67 & 2.64 & 1.82 \\
\hline-4 & -1.92 & -2.02 & 0.17 & 0.10 & -1.94 & -1.92 & -0.44 & -0.253 & -1.91 & -1.87 & 0.73 & 0.41 \\
\hline-3 & -2.49 & -2.61 & -2.32 & -1.22 & -2.63 & -2.60 & -3.07 & -1.519 & -2.35 & -2.29 & -1.62 & -0.79 \\
\hline-2 & -6.08 & -6.38 & -8.40 & -3.94 & -6.25 & -6.18 & -9.32 & -4.121 & -5.93 & -5.78 & -7.55 & -3.29 \\
\hline-1 & -3.45 & -3.62 & -11.85 & -5.08 & -3.21 & -3.17 & -12.53 & -5.058 & -3.65 & -3.56 & -11.20 & -4.46 \\
\hline 0 & -0.37 & -0.39 & -12.22 & -4.85 & -0.22 & -0.22 & -12.75 & -4.767 & -0.51 & -0.50 & -11.71 & -4.31 \\
\hline 1 & 0.25 & 0.26 & -11.97 & -4.45 & 0.70 & 0.69 & -12.05 & -4.215 & -0.15 & -0.15 & -11.86 & -4.09 \\
\hline 2 & -0.61 & -0.64 & -12.58 & -4.40 & -0.55 & -0.54 & -12.60 & -4.154 & -0.67 & -0.65 & -12.53 & -4.07 \\
\hline 3 & -0.45 & -0.47 & -13.03 & -4.33 & -0.40 & -0.40 & -13.00 & -4.066 & -0.48 & -0.47 & -13.01 & -4.01 \\
\hline 4 & 0.24 & 0.26 & & -4.05 & 0.29 & 0.29 & -12.70 & -3.789 & 0.18 & 0.18 & -12.82 & -3.77 \\
\hline 5 & 0.47 & 0.50 & -12.31 & -3.73 & 0.65 & 0.65 & -12.05 & -3.441 & 0.32 & 0.32 & -12.50 & -3.52 \\
\hline 6 & 0.85 & 0.89 & -11.46 & -3.34 & 0.88 & 0.87 & -11.17 & -3.064 & 0.81 & 0.79 & -11.69 & -3.16 \\
\hline
\end{tabular}

Note: Yousing price changes are considered as returns on a "housing" portfolio. Abnormal returns are calculated using two models of normal returns, the constant mean return and the market model return. Event month is the month in which the policy is effective. Event window spreads 13 month with 6 months before and 6 months after the event month. Estimation window includes 42 months prior to the event window. Three portfolios are considered: national, the urban and rural areas. CAR is the cumulative abnormal return for month -6 to the specific month. Results using constant mean model of normal returns are reported in the top table; and the market model of normal returns are presented in the bottom table. The event month is January 2009. 
For each of the above policy changes above, the estimation window is 42 months prior to the event window, which covers a 13 month period with 6 months before and 6 months after the event month. We use both constant mean return and market model return to estimate the abnormal returns in the even window. Tables 1-5 represent the statistics and test results.

With respect to the changes in corporate income tax and non-farm land use tax, we do not find significant effect on the housing prices in all three samples, as seen by both the abnormal returns and the cumulative abnormal returns
(Tables 4 and 5), although the cumulative abnormal returns decline sharply after the events. For the personal income tax, the introduction (Table 1) and the modifications (Tables 2 and 3) of it show significant overall interference on housing prices in all three samples, as seen by the cumulative abnormal returns, which decline around 8 to 12 percent during the window period. This interference is found significant starting 2 months prior to the event, and less after that. The introduction of personal income tax also causes significant decline in the housing prices in each of the four months prior to the event (Table 1).

Table 2. Effect of the modification to personal income tax law on housing price

\begin{tabular}{|c|c|c|c|c|c|c|c|c|c|c|c|c|}
\hline \multicolumn{13}{|c|}{ Constant Mean Return } \\
\hline \multicolumn{5}{|c|}{ National } & \multicolumn{4}{|c|}{ Urban } & \multicolumn{4}{|c|}{ Rural } \\
\hline$\tau$ & $A R, \%$ & t-stat & CAR, \% & t-stat & $A R, \%$ & t-stat & CAR, \% & t-stat & $\underset{\%}{\mathrm{AR},}$ & t-stat & $\underset{\%}{\text { CAR, }}$ & t-stat \\
\hline-6 & -0.74 & -0.60 & -0.74 & -0.60 & -0.82 & -0.62 & -0.82 & -0.62 & -0.68 & -0.57 & -0.68 & -0.57 \\
\hline-5 & -0.65 & -0.53 & -1.39 & -0.80 & -0.76 & -0.58 & -1.58 & -0.85 & -0.59 & -0.49 & -1.27 & -0.75 \\
\hline-4 & -1.01 & -0.82 & -2.40 & -1.13 & -1.06 & -0.80 & -2.64 & -1.16 & -0.97 & -0.81 & -2.24 & -1.08 \\
\hline-3 & -1.54 & -1.26 & -3.94 & -1.61 & -1.74 & -1.32 & -4.38 & -1.66 & -1.43 & -1.20 & -3.67 & -1.54 \\
\hline-2 & -1.63 & -1.33 & -5.58 & -2.03 & -1.83 & -1.39 & -6.21 & -2.10 & -1.47 & -1.23 & -5.13 & -1.93 \\
\hline-1 & -1.08 & -0.88 & -6.66 & -2.21 & -1.17 & -0.89 & -7.38 & -2.28 & -1.02 & -0.86 & -6.15 & -2.11 \\
\hline 0 & -0.67 & -0.55 & -7.33 & -2.26 & -0.76 & -0.58 & -8.14 & -2.33 & -0.61 & -0.51 & -6.76 & -2.15 \\
\hline 1 & -0.22 & -0.18 & -7.55 & -2.17 & -0.30 & -0.23 & -8.44 & -2.26 & -0.10 & -0.08 & -6.86 & -2.04 \\
\hline 2 & -0.19 & -0.16 & -7.74 & -2.10 & -0.16 & -0.12 & -8.60 & -2.17 & -0.19 & -0.16 & -7.05 & -1.97 \\
\hline 3 & -0.60 & -0.49 & -8.34 & -2.15 & -0.74 & -0.56 & -9.34 & -2.24 & -0.49 & -0.41 & -7.54 & -2.00 \\
\hline 4 & -0.69 & -0.56 & -9.03 & -2.22 & -0.77 & -0.58 & -10.11 & -2.31 & -0.61 & -0.51 & -8.15 & -2.06 \\
\hline 5 & 1.21 & 0.98 & -7.82 & -1.84 & 1.48 & 1.12 & -8.63 & -1.89 & 1.13 & 0.95 & -7.02 & -1.70 \\
\hline 6 & -0.08 & -0.07 & -7.91 & -1.79 & 0.02 & 0.01 & -8.61 & -1.81 & -0.11 & -0.09 & -7.12 & -1.66 \\
\hline \multicolumn{13}{|c|}{ Market Model Return } \\
\hline \multicolumn{5}{|c|}{ National } & \multicolumn{4}{|c|}{ Urban } & \multicolumn{4}{|c|}{ Rural } \\
\hline$\tau$ & $A R, \%$ & t-stat & CAR, \% & t-stat & $A R, \%$ & t-stat & CAR, \% & t-stat & $\underset{\%}{\mathrm{AR}}$ & t-stat & $\underset{\%}{\text { CAR, }}$ & t-stat \\
\hline-6 & -1.38 & -1.15 & -1.38 & -1.15 & -1.41 & -1.10 & -1.41 & -1.10 & -1.36 & -1.16 & -1.36 & -1.16 \\
\hline-5 & -0.61 & -0.51 & -1.98 & -1.17 & -0.67 & -0.52 & -2.07 & -1.15 & -0.59 & -0.50 & -1.94 & -1.17 \\
\hline-4 & -1.15 & -0.96 & -3.13 & -1.51 & -1.15 & -0.90 & -3.22 & -1.46 & -1.15 & -0.98 & -3.09 & -1.53 \\
\hline-3 & -1.41 & -1.17 & -4.54 & -1.89 & -1.56 & -1.22 & -4.78 & -1.87 & -1.34 & -1.14 & -4.43 & -1.89 \\
\hline-2 & -2.00 & -1.67 & -6.54 & -2.44 & -2.15 & -1.68 & -6.93 & -2.42 & -1.88 & -1.61 & -6.31 & -2.41 \\
\hline-1 & -0.79 & -0.66 & -7.33 & -2.50 & -0.83 & -0.65 & -7.76 & -2.48 & -0.77 & -0.66 & -7.08 & -2.47 \\
\hline 0 & -0.76 & -0.63 & -8.09 & -2.55 & -0.80 & -0.63 & -8.56 & -2.53 & -0.74 & -0.63 & -7.82 & -2.53 \\
\hline 1 & -0.06 & -0.05 & -8.16 & -2.41 & -0.09 & -0.07 & -8.66 & -2.39 & 0.02 & 0.01 & -7.81 & -2.36 \\
\hline 2 & -0.36 & -0.30 & -8.51 & -2.37 & -0.28 & -0.22 & -8.93 & -2.33 & -0.40 & -0.34 & -8.20 & -2.34 \\
\hline 3 & -0.64 & -0.53 & -9.15 & -2.42 & -0.73 & -0.57 & -9.66 & -2.39 & -0.57 & -0.49 & -8.77 & -2.37 \\
\hline 4 & -0.77 & -0.65 & -9.93 & -2.50 & -0.80 & -0.63 & -10.47 & -2.47 & -0.73 & -0.63 & -9.51 & -2.45 \\
\hline 5 & 1.23 & 1.03 & -8.69 & -2.09 & 1.55 & 1.22 & -8.91 & -2.01 & 1.11 & 0.95 & -8.39 & -2.07 \\
\hline 6 & -0.49 & -0.41 & -9.18 & -2.13 & -0.34 & -0.27 & -9.25 & -2.01 & -0.56 & -0.48 & -8.95 & -2.12 \\
\hline
\end{tabular}

Note: The event month is July 2013. 
Table 3. Effect of the modification to personal income tax law on housing price

\begin{tabular}{|c|c|c|c|c|c|c|c|c|c|c|c|c|}
\hline \multicolumn{13}{|c|}{ Constant Mean Return } \\
\hline \multicolumn{5}{|c|}{ National } & \multicolumn{4}{|c|}{ Urban } & \multicolumn{4}{|c|}{ Rural } \\
\hline$\tau$ & $\mathrm{AR}, \%$ & t-stat & $\underset{\%}{\text { CAR, }}+$ & t-stat & $A R, \%$ & t-stat & CAR, \% & t-stat & $A R, \%$ & t-stat & CAR, \% & t-stat \\
\hline-6 & -0.30 & -0.24 & -0.30 & -0.24 & -0.32 & -0.23 & -0.32 & -0.23 & -0.26 & -0.21 & -0.26 & -0.21 \\
\hline-5 & -1.04 & -0.82 & -1.34 & -0.75 & -1.10 & -0.79 & -1.42 & -0.73 & -0.99 & -0.81 & -1.25 & -0.72 \\
\hline-4 & -1.11 & -0.88 & -2.45 & -1.12 & -1.17 & -0.85 & -2.59 & -1.08 & -1.07 & -0.87 & -2.33 & -1.09 \\
\hline-3 & -0.81 & -0.64 & -3.26 & -1.29 & -0.82 & -0.59 & -3.41 & -1.23 & -0.79 & -0.64 & -3.12 & -1.27 \\
\hline-2 & -1.47 & -1.16 & -4.72 & -1.67 & -1.60 & -1.16 & -5.01 & -1.62 & -1.41 & -1.15 & -4.53 & -1.65 \\
\hline-1 & -1.72 & -1.36 & -6.44 & -2.08 & -1.90 & -1.37 & -6.91 & -2.04 & -1.63 & -1.33 & -6.16 & -2.05 \\
\hline 0 & -1.82 & -1.44 & -8.26 & -2.47 & -2.00 & -1.44 & -8.92 & -2.43 & -1.67 & -1.36 & -7.84 & -2.41 \\
\hline 1 & -1.14 & -0.90 & -9.40 & -2.63 & -1.17 & -0.85 & -10.09 & -2.57 & -1.14 & -0.93 & -8.98 & -2.58 \\
\hline 2 & -0.57 & -0.45 & -9.97 & -2.63 & -0.48 & -0.35 & -10.57 & -2.54 & -0.61 & -0.50 & -9.59 & -2.60 \\
\hline 3 & 0.11 & 0.09 & -9.86 & -2.46 & 0.11 & 0.08 & -10.46 & -2.39 & 0.13 & 0.10 & -9.46 & -2.43 \\
\hline 4 & 0.54 & 0.43 & -9.32 & -2.22 & 0.83 & 0.60 & -9.63 & -2.10 & 0.65 & 0.53 & -8.82 & -2.16 \\
\hline 5 & -0.43 & -0.34 & -9.75 & -2.22 & -0.47 & -0.34 & -10.10 & -2.10 & -0.40 & -0.33 & -9.22 & -2.16 \\
\hline 6 & -0.51 & -0.40 & -10.25 & -2.25 & -0.54 & -0.39 & -10.64 & -2.13 & -0.50 & -0.41 & -9.72 & -2.19 \\
\hline \multicolumn{13}{|c|}{ Market Model Return } \\
\hline \multicolumn{5}{|c|}{ National } & \multicolumn{4}{|c|}{ Urban } & \multicolumn{4}{|c|}{ Rural } \\
\hline$\tau$ & $A R, \%$ & t-stat & $\begin{array}{c}\text { CAR, } \\
\%\end{array}$ & t-stat & $\mathrm{AR}, \%$ & t-stat & CAR, \% & t-stat & $\mathrm{AR}, \%$ & t-stat & CAR, \% & t-stat \\
\hline-6 & -0.33 & -0.26 & -0.33 & -0.26 & -0.38 & -0.27 & -0.38 & -0.27 & -0.27 & -0.22 & -0.27 & -0.22 \\
\hline-5 & -1.10 & -0.87 & -1.43 & -0.80 & -1.19 & -0.87 & -1.57 & -0.80 & -1.03 & -0.85 & -1.30 & -0.76 \\
\hline-4 & -1.04 & -0.82 & -2.47 & -1.13 & -1.13 & -0.82 & -2.70 & -1.13 & -0.98 & -0.81 & -2.28 & -1.08 \\
\hline-3 & -0.81 & -0.64 & -3.28 & -1.30 & -0.85 & -0.61 & -3.55 & -1.29 & -0.77 & -0.63 & -3.05 & -1.25 \\
\hline-2 & -1.40 & -1.11 & -4.68 & -1.66 & -1.56 & -1.13 & -5.11 & -1.66 & -1.32 & -1.09 & -4.37 & -1.61 \\
\hline-1 & -1.67 & -1.32 & -6.35 & -2.05 & -1.88 & -1.37 & -6.99 & -2.07 & -1.56 & -1.29 & -5.93 & -1.99 \\
\hline 0 & -1.87 & -1.48 & -8.22 & -2.46 & -2.08 & -1.51 & -9.07 & -2.49 & -1.70 & -1.40 & -7.63 & -2.38 \\
\hline 1 & -1.16 & -0.92 & -9.38 & -2.63 & -1.22 & -0.89 & -10.29 & -2.64 & -1.14 & -0.94 & -8.77 & -2.56 \\
\hline 2 & -0.49 & -0.39 & -9.87 & -2.60 & -0.43 & -0.31 & -10.72 & -2.59 & -0.51 & -0.42 & -9.28 & -2.55 \\
\hline 3 & 0.10 & 0.08 & -9.78 & -2.45 & 0.07 & 0.05 & -10.66 & -2.44 & 0.14 & 0.11 & -9.15 & -2.38 \\
\hline 4 & 0.53 & 0.42 & -9.24 & -2.21 & 0.79 & 0.58 & -9.86 & -2.16 & 0.66 & 0.55 & -8.48 & -2.11 \\
\hline 5 & -0.47 & -0.37 & -9.71 & -2.22 & -0.54 & -0.39 & -10.40 & -2.18 & -0.42 & -0.34 & -8.90 & -2.12 \\
\hline 6 & -0.55 & -0.44 & -10.26 & -2.25 & -0.61 & -0.44 & -11.01 & -2.21 & -0.52 & -0.43 & -9.42 & -2.15 \\
\hline
\end{tabular}

Note: The event month is January 2015.

Table 4. Effect of the modification to corporate income tax law on housing price

\begin{tabular}{|c|c|c|c|c|c|c|c|c|c|c|c|c|}
\hline \multicolumn{13}{|c|}{ Constant Mean Return } \\
\hline \multicolumn{5}{|c|}{ National } & \multicolumn{4}{|c|}{ Urban } & \multicolumn{4}{|c|}{ Rural } \\
\hline$\tau$ & $A R, \%$ & t-stat & CAR, $\%$ & t-stat & $A R, \%$ & t-stat & CAR, $\%$ & t-stat & $A R, \%$ & t-stat & CAR, $\%$ & t-stat \\
\hline-6 & -0.52 & -0.40 & -0.52 & -0.40 & -0.58 & -0.42 & -0.58 & -0.42 & -0.48 & -0.38 & -0.48 & -0.38 \\
\hline-5 & -0.07 & -0.05 & -0.59 & -0.32 & -0.12 & -0.09 & -0.70 & -0.36 & 0.03 & 0.03 & -0.44 & -0.25 \\
\hline-4 & -0.04 & -0.03 & -0.62 & -0.28 & 0.02 & 0.02 & -0.68 & -0.28 & -0.06 & -0.05 & -0.50 & -0.23 \\
\hline-3 & -0.45 & -0.35 & -1.07 & -0.42 & -0.56 & -0.40 & -1.24 & -0.44 & -0.36 & -0.29 & -0.86 & -0.34 \\
\hline-2 & -0.54 & -0.42 & -1.61 & -0.56 & -0.59 & -0.42 & -1.83 & -0.59 & -0.48 & -0.38 & -1.33 & -0.48 \\
\hline-1 & 1.36 & 1.06 & -0.25 & -0.08 & 1.66 & 1.20 & -0.16 & -0.05 & 1.26 & 1.02 & -0.07 & -0.02 \\
\hline 0 & 0.07 & 0.06 & -0.18 & -0.05 & 0.20 & 0.14 & 0.04 & 0.01 & 0.02 & 0.02 & -0.05 & -0.01 \\
\hline 1 & -1.59 & -1.23 & -1.76 & -0.48 & -1.87 & -1.35 & -1.83 & -0.47 & -1.41 & -1.13 & -1.45 & -0.41 \\
\hline 2 & -1.69 & -1.31 & -3.45 & -0.89 & -1.92 & -1.38 & -3.75 & -0.90 & -1.56 & -1.25 & -3.01 & -0.81 \\
\hline 3 & -1.51 & -1.17 & -4.96 & -1.22 & -1.89 & -1.36 & -5.64 & -1.28 & -1.26 & -1.01 & -4.26 & -1.09 \\
\hline 4 & -0.52 & -0.40 & -5.48 & -1.28 & -0.57 & -0.41 & -6.21 & -1.35 & -0.48 & -0.38 & -4.74 & -1.15 \\
\hline 5 & -0.34 & -0.26 & -5.81 & -1.30 & -0.33 & -0.24 & -6.54 & -1.36 & -0.33 & -0.26 & -5.07 & -1.18 \\
\hline 6 & -0.52 & -0.40 & -6.33 & -1.36 & -0.59 & -0.42 & -7.13 & -1.42 & -0.44 & -0.35 & -5.50 & -1.23 \\
\hline
\end{tabular}


Table 4 (cont). Effect of the modification to corporate income tax law on housing price

\begin{tabular}{|c|c|c|c|c|c|c|c|c|c|c|c|c|}
\hline \multicolumn{13}{|c|}{ Market Model Return } \\
\hline \multicolumn{5}{|c|}{ National } & \multicolumn{4}{|c|}{ Urban } & \multicolumn{4}{|c|}{ Rural } \\
\hline$\tau$ & $\mathrm{AR}, \%$ & t-stat & CAR, $\%$ & t-stat & $\mathrm{AR}, \%$ & t-stat & CAR, \% & t-stat & AR, \% & t-stat & CAR, \% & t-stat \\
\hline-6 & -0.59 & -0.46 & -0.59 & -0.46 & -0.63 & -0.46 & -0.63 & -0.46 & -0.57 & -0.46 & -0.57 & -0.46 \\
\hline-5 & 0.06 & 0.05 & -0.52 & -0.29 & 0.03 & 0.02 & -0.59 & -0.31 & 0.14 & 0.11 & -0.42 & -0.24 \\
\hline-4 & -0.17 & -0.13 & -0.69 & -0.31 & -0.09 & -0.06 & -0.68 & -0.29 & -0.21 & -0.17 & -0.63 & -0.30 \\
\hline-3 & -0.47 & -0.37 & -1.17 & -0.46 & -0.56 & -0.41 & -1.25 & -0.46 & -0.40 & -0.33 & -1.04 & -0.42 \\
\hline-2 & -0.60 & -0.47 & -1.77 & -0.62 & -0.63 & -0.46 & -1.88 & -0.62 & -0.56 & -0.46 & -1.60 & -0.58 \\
\hline-1 & 1.39 & 1.09 & -0.38 & -0.12 & 1.71 & 1.25 & -0.17 & -0.05 & 1.27 & 1.03 & -0.33 & -0.11 \\
\hline 0 & -0.25 & -0.20 & -0.63 & -0.19 & -0.10 & -0.08 & -0.27 & -0.08 & -0.32 & -0.26 & -0.65 & -0.20 \\
\hline 1 & -1.76 & -1.38 & -2.39 & -0.67 & -2.02 & -1.48 & -2.29 & -0.59 & -1.60 & -1.30 & -2.25 & -0.65 \\
\hline 2 & -1.71 & -1.35 & -4.10 & -1.08 & -1.92 & -1.41 & -4.21 & -1.03 & -1.60 & -1.30 & -3.85 & -1.05 \\
\hline 3 & -1.43 & -1.13 & -5.53 & -1.38 & -1.79 & -1.31 & -6.00 & -1.39 & -1.20 & -0.98 & -5.05 & -1.30 \\
\hline 4 & -0.43 & -0.33 & -5.96 & -1.41 & -0.46 & -0.33 & -6.46 & -1.43 & -0.41 & -0.33 & -5.46 & -1.34 \\
\hline 5 & -0.43 & -0.33 & -6.38 & -1.45 & -0.40 & -0.29 & -6.85 & -1.45 & -0.44 & -0.35 & -5.89 & -1.38 \\
\hline 6 & -0.61 & -0.48 & -7.00 & -1.53 & -0.66 & -0.49 & -7.52 & -1.53 & -0.55 & -0.45 & -6.45 & -1.46 \\
\hline
\end{tabular}

Note: The event month is January 2014.

Table 5. Effect of the introduction of the non-farm land use tax law on housing price

\begin{tabular}{|c|c|c|c|c|c|c|c|c|c|c|c|c|}
\hline \multicolumn{13}{|c|}{ Constant Mean Return } \\
\hline \multicolumn{5}{|c|}{ National } & \multicolumn{4}{|c|}{ Urban } & \multicolumn{4}{|c|}{ Rural } \\
\hline$\tau$ & $\mathrm{AR}, \%$ & t-stat & CAR, \% & t-stat & $A R, \%$ & t-stat & CAR, \% & t-stat & $\mathrm{AR}, \%$ & t-stat & CAR, \% & t-stat \\
\hline-6 & -0.81 & -0.50 & -0.81 & -0.50 & -0.88 & -0.55 & -0.88 & -0.55 & -0.78 & -0.47 & -0.78 & -0.47 \\
\hline-5 & -0.28 & -0.17 & -1.09 & -0.48 & -0.17 & -0.11 & -1.04 & -0.47 & -0.34 & -0.21 & -1.13 & -0.48 \\
\hline-4 & -0.80 & -0.50 & -1.89 & -0.68 & -0.88 & -0.55 & -1.92 & -0.70 & -0.74 & -0.44 & -1.87 & -0.65 \\
\hline-3 & -1.20 & -0.74 & -3.09 & -0.96 & -1.51 & -0.95 & -3.43 & -1.08 & -0.97 & -0.58 & -2.85 & -0.85 \\
\hline-2 & -1.05 & -0.65 & -4.14 & -1.15 & -1.22 & -0.77 & -4.64 & -1.31 & -0.92 & -0.55 & -3.77 & -1.01 \\
\hline-1 & -0.66 & -0.41 & -4.80 & -1.22 & -0.62 & -0.39 & -5.26 & -1.36 & -0.69 & -0.41 & -4.47 & -1.09 \\
\hline 0 & 0.54 & 0.34 & -4.26 & -1.00 & 0.60 & 0.38 & -4.66 & -1.11 & 0.56 & 0.33 & -3.91 & -0.88 \\
\hline 1 & 1.30 & 0.81 & -2.96 & -0.65 & 1.73 & 1.10 & -2.92 & -0.65 & 1.08 & 0.64 & -2.83 & -0.60 \\
\hline 2 & 1.14 & 0.71 & -1.82 & -0.38 & 1.40 & 0.89 & -1.52 & -0.32 & 1.04 & 0.62 & -1.80 & -0.36 \\
\hline 3 & -1.61 & -1.00 & -3.43 & -0.67 & -1.73 & -1.09 & -3.25 & -0.65 & -1.59 & -0.95 & -3.39 & -0.64 \\
\hline 4 & -2.14 & -1.33 & -5.57 & -1.04 & -2.48 & -1.56 & -5.72 & -1.09 & -1.96 & -1.17 & -5.36 & -0.97 \\
\hline 5 & -2.38 & -1.48 & -7.95 & -1.42 & -2.71 & -1.71 & -8.43 & -1.54 & -2.20 & -1.32 & -7.56 & -1.30 \\
\hline 6 & -2.10 & -1.30 & -10.05 & -1.73 & -2.46 & -1.55 & -10.89 & -1.91 & -1.87 & -1.12 & -9.44 & -1.56 \\
\hline \multicolumn{13}{|c|}{ Market Model Return } \\
\hline \multicolumn{5}{|c|}{ National } & \multicolumn{4}{|c|}{ Urban } & \multicolumn{4}{|c|}{ Rural } \\
\hline$\tau$ & $A R, \%$ & t-stat & CAR, \% & t-stat & $A R, \%$ & t-stat & CAR, \% & t-stat & $\mathrm{AR}, \%$ & t-stat & CAR, $\%$ & t-stat \\
\hline-6 & -0.74 & -0.46 & -0.74 & -0.46 & -0.79 & -0.50 & -0.79 & -0.50 & -0.73 & -0.44 & -0.73 & -0.44 \\
\hline-5 & -0.36 & -0.23 & -1.10 & -0.49 & -0.23 & -0.15 & -1.02 & -0.46 & -0.44 & -0.27 & -1.17 & -0.50 \\
\hline-4 & -0.83 & -0.52 & -1.93 & -0.69 & -0.89 & -0.56 & -1.91 & -0.70 & -0.79 & -0.47 & -1.96 & -0.68 \\
\hline-3 & -1.19 & -0.74 & -3.12 & -0.97 & -1.48 & -0.95 & -3.39 & -1.08 & -0.98 & -0.59 & -2.94 & -0.88 \\
\hline-2 & -0.93 & -0.58 & -4.05 & -1.13 & -1.08 & -0.69 & -4.47 & -1.27 & -0.82 & -0.49 & -3.76 & -1.01 \\
\hline-1 & -0.56 & -0.35 & -4.61 & -1.17 & -0.50 & -0.32 & -4.97 & -1.29 & -0.61 & -0.37 & -4.37 & -1.07 \\
\hline 0 & 0.37 & 0.23 & -4.24 & -1.00 & 0.45 & 0.29 & -4.52 & -1.09 & 0.37 & 0.22 & -4.00 & -0.91 \\
\hline 1 & 1.15 & 0.72 & -3.09 & -0.68 & 1.60 & 1.02 & -2.92 & -0.66 & 0.91 & 0.55 & -3.09 & -0.65 \\
\hline 2 & 1.06 & 0.66 & -2.02 & -0.42 & 1.34 & 0.86 & -1.57 & -0.33 & 0.94 & 0.57 & -2.14 & -0.43 \\
\hline 3 & -1.73 & -1.08 & -3.76 & -0.74 & -1.83 & -1.17 & -3.41 & -0.69 & -1.73 & -1.04 & -3.88 & -0.74 \\
\hline 4 & -2.02 & -1.26 & -5.78 & -1.09 & -2.34 & -1.49 & -5.75 & -1.10 & -1.86 & -1.11 & -5.74 & -1.04 \\
\hline 5 & -2.37 & -1.48 & -8.15 & -1.47 & -2.68 & -1.71 & -8.43 & -1.55 & -2.21 & -1.33 & -7.95 & -1.38 \\
\hline 6 & -2.09 & -1.30 & -10.24 & -1.77 & -2.43 & -1.55 & -10.86 & -1.92 & -1.88 & -1.13 & -9.83 & -1.63 \\
\hline
\end{tabular}

Note: The event month is January 2012. 
The findings suggest that personal income tax policy plays a key role in the housing prices in Vietnam during the study period. Although our results have not shown the mechanism through which personal income tax policy has influenced the housing prices as in typical event study approach, it is still meaningful to draw implications for policy makers. In terms of state management of the housing market, if the government wants to manage the housing market through taxation, personal income tax policy could be most effective. The fact that price changes mostly happened prior to, and not much after, the effective date of the tax policy change indicates that tax policy changes indeed have influenced the housing prices. Broadly speaking, policies that correlate to personal income in general should be effective to controlling housing prices. This is similar to findings from the literature such as Adams and Fuss (2010), Goodhart and Hofmann (2008), or Madsen (2012).

\section{CONCLUSION}

The effect of tax policy on housing prices has been documented in the literature with little evidence on the direct relationship. Most research studies have examined the effect of tax policy on level of investments supplied by developers and on the level of income that influences the demand for housing by buyers to implicitly conclude on the effect on housing prices (ECB, 2009; Andrews, 2010; Poterba, 1992; Skinner, 1996; Gervais, 2002; Feldstein, 1982; Berkovec \& Fullerton, 1992). There are only few research studies that have provided evidences for the direct relationship between tax policy and housing prices (Goulder, 1989; Best \& Kleven, 2017; Bai et al., 2014; Du \& Zhang, 2015; Capozza et al., 1998; Rosenthal, 1999). Various forms of tax policies and reforms have been studied and although results are varying, they have all agreed on that tax policy plays an important role in determining housing prices.

In Vietnam, to the best of our knowledge, there has not been any research in this area found in the literature. During the past period from 2004 to 2016, the average housing prices in Vietnam increased 2.6 times, during which housing prices surged dramatically between 2004 and 2008 and stabilized or gradually increased after that. One reason for this change in housing price pattern might be because of the major changes in tax policies in Vietnam from 2008 and afterwards that were designed to curb and stabilize the housing market. It is, therefore, important for policy makers to understand if indeed it was the tax policy changes and reforms that played the role on housing market. The conclusion on this would be important for the government to utilize their tax policies as a tool to manage housing prices in the future.

This paper has examined the effect of tax policy on housing prices in Vietnam and offered policy recommendations for the Vietnamese government to help them monitor the housing prices through their taxation. Our research is the first paper that looks at the impact of tax policy changes on housing prices in Vietnam, and perhaps of the few papers in the literature that use event study approach to gauge this impact (a relevant example is Kuttner \& Shim, 2016). We have selected five events representing five key tax policy changes made to personal income tax, corporate income tax, and non-farm land use tax in this study.

Our research findings suggest that all five key changes made to personal income tax, corporate income tax and non-farm land use tax have caused the housing prices to decline on average 6-11\% during the 13 month window period but only the personal income tax change in January 2009 sees statistically significant impact. This implies that the personal income tax policy could be one of the key influential factors that determine housing prices. And hence, in order to monitor the housing market, in term of tax policy, the government could use personal income tax as a monitoring tool. We understand that an in-depth analysis of the mechanisms through which personal income tax has influenced housing prices should make this policy recommendation more complete, but we leave this for further research. 


\section{ACKNOWLEDGMENT}

This research is funded by Vietnam National Foundation for Science and Technology Development (NAFOSTED) under grant number II5.3 - 2013.03.

\section{REFERENCES}

1. Adams, Z., \& Füss, R. (2010). Macroeconomic determinants of international housing markets. Journal of Housing Economics, 19(1), 38-50. https://doi. org/10.1016/j.jhe.2009.10.005

2. Andrews, D. (2010). Real house prices in OECD countries: The role of demand shocks and structural and policy factors (OECD Economics Department Working Papers, No. 831). OECD Publishing. http://dx.doi. org/10.1787/5km33bqzhbzr-en

3. Apergis, N., \& Rezitis, A. (2003). Housing prices and macroeconomic factors in Greece: prospects within the EMU. Applied Economics Letters, 10(9), 561-565. https://doi.org/10.1080/1350485032000100260

4. Baffoe-Bonnie, J. (1998).

The dynamic impact of macroeconomic aggregates on housing prices and stock of houses: a national and regional analysis. Journal of Real Estate Finance and Economics, 17(2), 179-197. https:// doi.org/10.1023/A:1007753421236

5. Bai, C., Li, Q., \& Ouyang, M. (2014). Property taxes and home prices: A tale of two cities. Journal of Econometrics, 180(1), 1-15. https://doi.org/10.1016/j.jeconom.2013.08.039

6. Berkovec, J., \& Fullerton, D. (1989). The general equilibrium effects of inflation on housing consumption and investment. American Economic Review, 79, 277-282. Retrieved from http://www.jstor. org/stable/1827770

7. Berkovec, J., \& Fullerton, D. (1992). A general equilibrium model of housing, taxes, and portfolio choice. Journal of Political Economy, 100(2), 390-429. Retrieved from http://www.jstor.org/stable/2138612
8. Best, M. C., \& Kleven, H. J. (2018) Housing Market Responses to Transaction Taxes: Evidence From Notches and Stimulus in the UK. The Review of Economic Studies, 85(1), 157-193. https://doi. org/10.1093/restud/rdx032

9. Bork, L., \& Møller, S. V. (2016). Housing Price Forecastability: A Factor Analysis. Real Estate Economics. https://doi. org/10.1111/1540-6229.12185

10. Capozza, D., R., Green, R. K., \& Hendershott, P. H. (1998). Taxes and House Prices (Working Paper February No. 3, 1999). Retrieved from http://www.umich. edu/ reecon/restate/faculty/ Capozza/tax1097b.pdf

11. Case, K. E., Glaeser, E. L., \& Parker, J. A. (2000). Real estate and the macroeconomy. Brookings Papers on Economic Activity, 2, 119-162. https://doi.org/10.1353/ eca.2000.0011

12. Du, Z., \& Zhang, L. (2015). Homepurchase restriction, property tax and housing price in China: $\mathrm{A}$ counterfactual analysis. Journal of Econometrics, 188, 558-568. https://doi.org/10.1016/j.jeconom.2015.03.018

13. ECB (2009). Housing finance in the euro area (Occasional Paper Series 101, European Central Bank). Retrieved from http://www. ecb.europa.eu/pub/pdf/scpops/ ecbocp101.pdf

14. Feldstein, M. (1982). Inflation, tax rules and accumulation of residential and non-residential capital. Scandinavian Journal of Economics, 84(2), 293-311. https:// doi.org/10.2307/3439641

15. Follain, J. R. (1982). Does inflation affect real behavior? The case of housing. Southern Economic Journal, 48, 570-82. https://doi. org/10.2307/1058651
16. General Statistics Office (2017). Socio-Economic Statistics Database, Hanoi, Vietnam.

17. Gervais, M. (2002). Housing taxation and capital accumulation. Journal of Monetary Economics, 49(7), 1461-1489. https:// doi.org/10.1016/S03043932(02)00172-1

18. Giussani, B., Hsai, M., \& Tsolacos, S. (1992). A comparative analysis of the major determinants of office rental values in Europe. Journal of Property Valuation and Investment, 11, 157-173. https://doi. org/10.1108/14635789310031487

19. Goodhart, C., \& Hofmann, B. (2008). House prices, money, credit, and the macroeconomy. Oxford Review of Economic Policy, 24(1), 180-205. Retrieved from www.jstor.org/stable/23606731

20. Goulder, L. H. (1989). Tax policy, housing prices, and housing investment. Regional Science and Urban Economics, 19(2), 281-304. https://doi.org/10.1016/01660462(89)90007-0

21. Igan, D., Kabundi, A., Simone, F., Pinheiro, M., \& Tamirisa, N. (2011). Housing, credit, and real activity cycles: Characteristics and comovement. Journal of Housing Economics, 20(3), 210-231. https:// doi.org/10.1016/j.jhe.2011.07.002

22. Kearl, J. H. (1979). Inflation, mortgages, and housing. Journal of Political Economy, 87, 1-29. Retrieved from www.jstor.org/ stable/1833085

23. Kuttner, K., \& Shim, I. (2016). Can non-interest rate policies stabilize housing markets? Evidence from a panel of 57 economies. Journal of Financial Stability, 26, 31-44. https://doi. org/10.1016/j.jfs.2016.07.014 
24. Lerbs, O. (2011). Is there a link between homeownership and unemployment? Evidence from German regional data. International Economics and Economic Policy, 8(4), 407-426. https://doi.org/10.1007/s10368011-0181-4

25. Leung, C. (2004).

Macroeconomics and housing: a review of the literature. Journal of Housing Economics, 13(4), 249-267. https://doi.org/10.1016/j. jhe.2004.09.002

26. MacKinlay, C. (1997). Event Studies in Economics and Finance. Journal of Economic Literature, 35, 13-39. Retrieved from www.jstor. org/stable/2729691

27. Madsen, J. (2012). A behavioural model of house prices. Journal of Economic Behavior \& Organization, 82(1), 21-38. https://doi. org/10.1016/j.jebo.2011.12.010

28. Mankiw, N., \& Weil, D. (1989). The baby boom, the baby bust, and the housing market. Regional science and urban economics, 19(2), 23558. https://doi.org/10.1016/01660462(89)90005-7
29. Mikhed, V., \& Zemcik, P. (2009). Do house prices reflect fundamentals? Aggregate and panel data evidence. Journal of Housing Economics, 18(2), 140149. https://doi.org/10.1016/j. jhe.2009.03.001

30. National Assembly (2007). Personal Income Tax Law. Hanoi, Vietnam.

31. National Assembly (2011). Changes and Additional Clauses to the Non-Farm Land Use Tax Law. Hanoi, Vietnam.

32. National Assembly (2013a). Changes and Additional Clauses to the Personal Income Tax Law. Hanoi, Vietnam.

33. National Assembly (2013b). Changes and Additional Clauses to the Corporate Income Tax Law. Hanoi, Vietnam.

34. National Assembly (2014). Changes and Additional Clauses to the Personal Income Tax Law. Hanoi, Vietnam.

35. Poterba, J. (1992). Taxation and housing: Old questions, new answers. American Economic
Review, 82, 237-242. Retrieved from www.jstor.org/stable/2117407

36. Rosenthal, L. (1999). House Prices and Local Taxes in the UK. Fiscal Studies, 20(1), 61-76. doi:10.1111/j.1475-5890.1999. tb00004.x

37. Skinner, J. (1996). The dynamic efficiency cost of not taxing housing. Journal of Public Economics, 59(3), 397-417. https://doi.org/10.1016/0047 2727(95)01509-4

38. Turnovsky, S., \& Okuyama, T. (1994). Taxes, housing, and capital accumulation in a two-sector growing economy. Journal of Public Economics, 53(2), 245-267. https://doi.org/10.1016/00472727(94)90023-X

39. Zan, Y., \& Wang, S. (2012). Permanent and transitory shocks in owner-occupied housing: A common trend model of price dynamics. Journal of Housing Economics, 21(4), 336-346. https://doi.org/10.1016/j. jhe.2012.08.001 